\title{
Archaeology and Archaeozoology of Phum Snay: \\ A Late Prehistoric Cemetery in Northwestern Cambodia
}

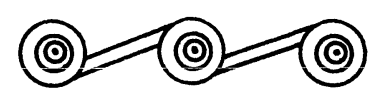

\author{
DOUGALD J. W. O'REILLY, ANGELA VON DEN DRIESCH, AND \\ VUTHY VOEUN
}

THIS PAPER FOCUSES ON THE ANALYSIS OF THE FAUNAL MATERIAL from a prehistoric site called Phum Snay, located in northwestern Cambodia. The prehistoric occupation of Phum Snay dates to the Iron Age (c. 500 B.C.-A.D. 500) and represents one of the first sites of this period excavated in Cambodia (for review, see Stark 2004:96-100). The archaeological significance of this site is clear, as it represents a settlement and cemetery.site that predates the rise of the great state of Angkor less than $100 \mathrm{~km}$ to the east. The faunal remains discussed herein were recovered from both the settlement activity at the site and from the interments.

The site is also of interest because of its proximity to sites of a similar age in northeastern Thailand excavated by the University of Otago's Origins of Angkor Archaeological Project. The mortuary ritual and artifact assemblage of Phum Snay may be compared and contrasted to that of sites such as Noen U-Loke (Chetwin n.d.; Higham 1998; Wichakana 1991), Ban Non Wat, and Non Muang Kao (O'Reilly 1998). The most striking similarities include the presence of comparable ceramic black wares and grave beds lined with either clay or what appears to be resin. The most striking difference appears to be the greater emphasis on weaponry of many of the burials at the Cambodian site. This observation, however, is based on a limited number of graves and may prove to be a result of sampling error.

Phum Snay is a village located along National Route 6 in Preah Net Prey District, Banteay Meanchey Province, northwestern Cambodia (48P UTM 0305983/ $150685613^{\circ} 37^{\prime} 26.3^{\prime \prime} \mathrm{N}, 103^{\circ} 12^{\prime} 23.5^{\prime \prime} \mathrm{E}$ ) (Fig. 1). The village is one of several small hamlets located on the edge of a large natural mound that is approximately $3 \mathrm{~km}$ in diameter. The Preah Net Prey River is located approximately $100 \mathrm{~m}$ to the west of the site. The archaeological remains at Phum Snay were discovered in 2000 , during the construction of a road.

Dougald J. W. O'Reilly is with Heritage Watch, Phnom Penh, Cambodia. Angela von den Driesch is with the Institut für Palaeoanatomie und Geschichte der Tiermedizin der Ludwig-Maximilians, Universität München, Germany. Vuthy Voeun is with the Royal University of Fine Arts, Faculty of Archaeology, Phnom Penh, Cambodia.

Asian Perspectives, Vol. 45, No. 2 (C) 2006 by the University of Hawai'i Press.

An earlier version of this article in German will be appearing in Beiträge zur Allgemeinen und Vergleichenden Archäologie (forthcoming). 


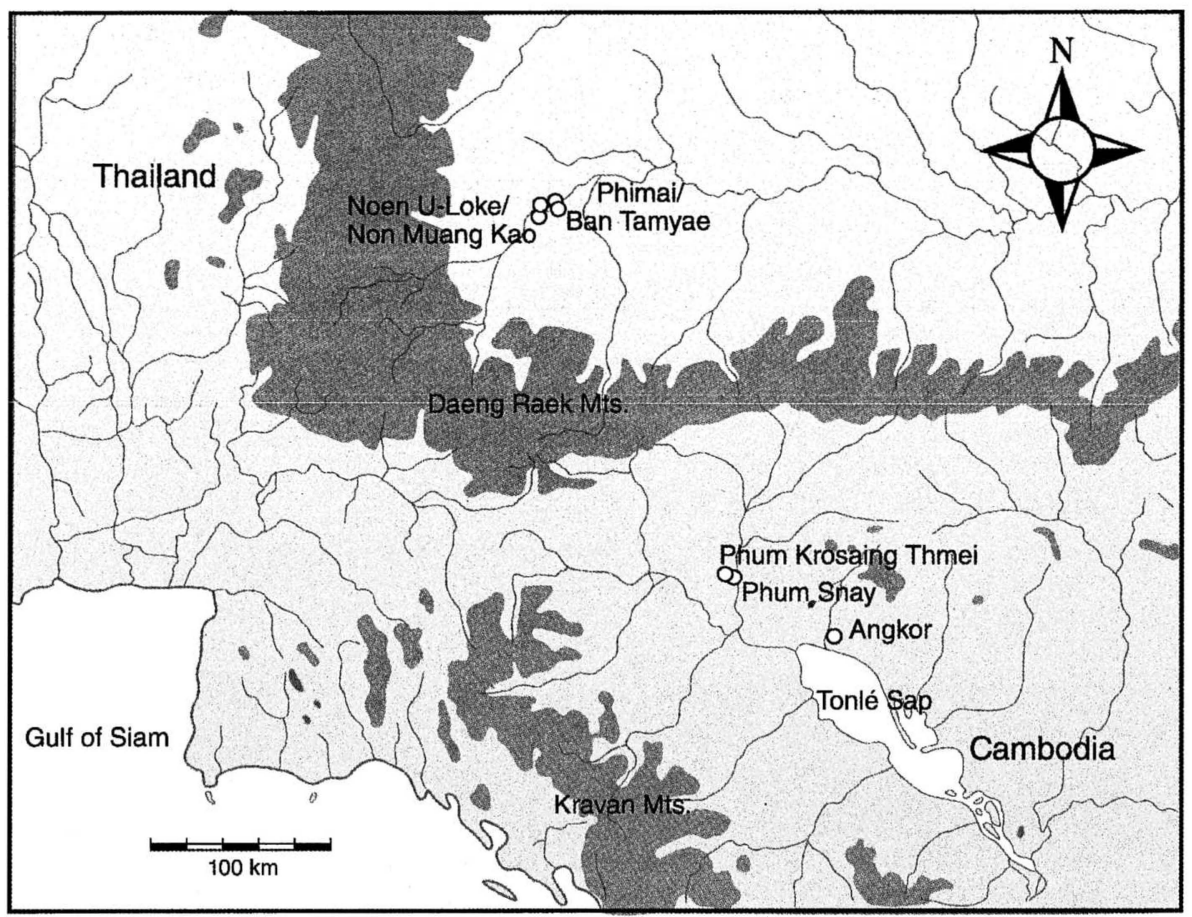

Fig. 1. Map of Cambodia showing the location of Phum Snay.

Excavations at Phum Snay were undertaken in 2001, 2002, and 2003 at three different locations (Fig. 2). In each instance the site was excavated in 10-cm spits. Major changes in the color of the matrix were signified by a change in the layer number, the uppermost being labeled Layer 1. The excavation in 2001 uncovered nine inhumation burials. Fourteen more burials were found during the 2003 campaign. The burials included the remains of men, women, and children buried in a supine position oriented on an east-west axis. Most burials contained grave goods, some of which were sexually differentiated. Some males were found with iron implements such as sickles, swords, daggers, and projectile points, while women more often were accompanied by semiprecious stones and spindle whorls. The graves of both sexes contained ceramic vessels, bronze ornaments including bangles, finger rings, and bells. Many of the individuals were associated with faunal remains that were placed in the grave at the time of the original interment.

The faunal remains discussed in this paper were recovered during the 2001 and 2003 excavations; none were recovered during the 2002 excavation. Burials from the first campaign are denoted in the text as Burial \#-'01. Those from the 2003 campaign are designated as Burial \#-'03. Although the bones recovered were in varying degrees of preservation, for the most part identification was possible.

Many samples were sent for radiocarbon dating, including charcoal, plant remains, and bones (Table 1). Due to the soil conditions, insufficient carbon was preserved in many of the samples. One date for each excavated area was eventually obtained. The area excavated in 2001 returned a date for the burials of 207 


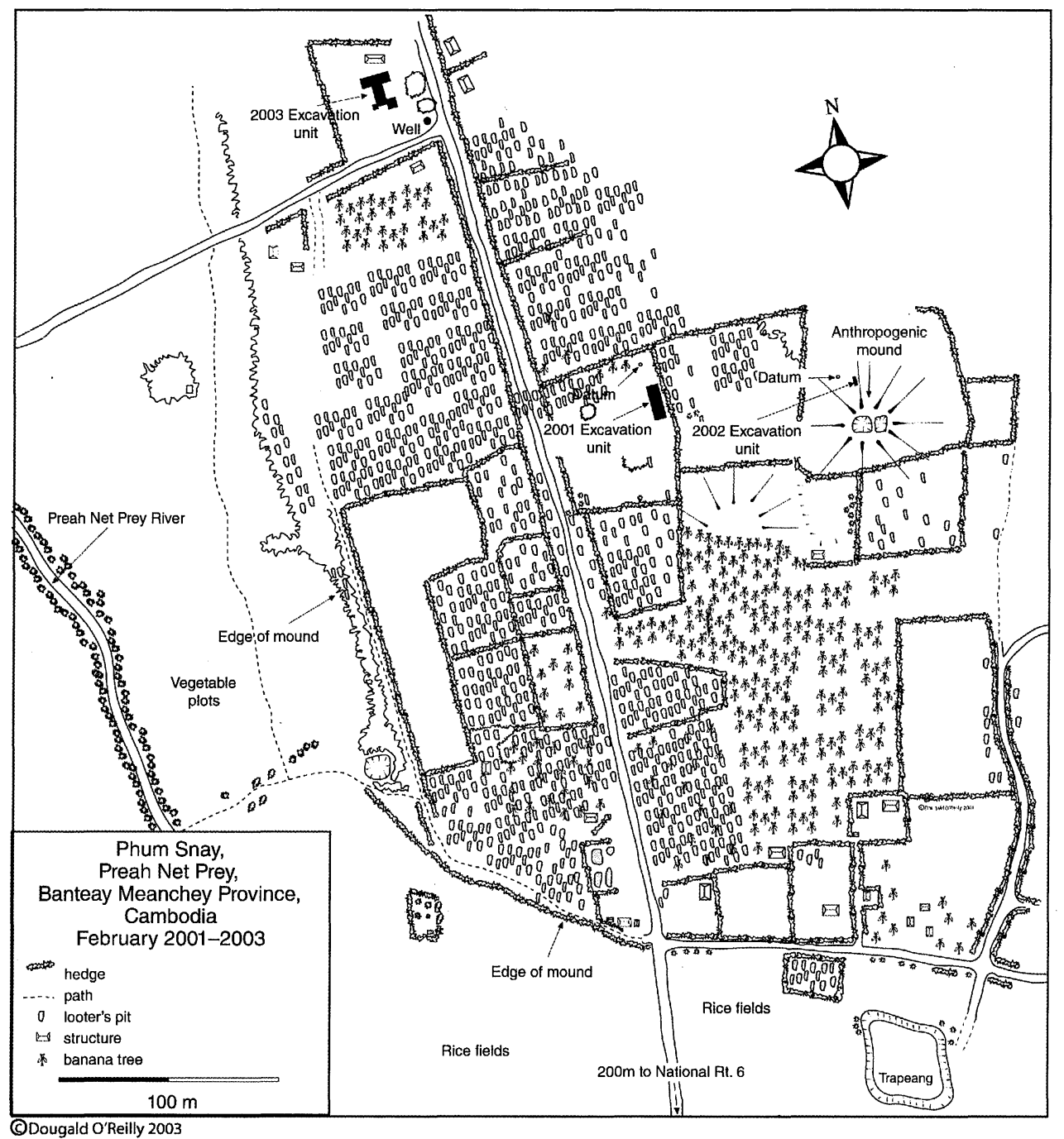

Fig. 2. The mound of Phum Snay with the excavated areas indicated in black.

Table i. Radiocarbon Determinations from Phum Snay and Phum Krosaing Thmei

\begin{tabular}{|c|c|c|c|}
\hline PROVENANCE/DATE & $\begin{array}{c}\text { LABORATORY } \\
\text { NO. }\end{array}$ & $\begin{array}{l}\text { CONVENTIONAL } \\
{ }^{\mathrm{I} 4 \mathrm{C} \text { AGE }}\end{array}$ & $\begin{array}{c}\text { CALIBRATED AGE } 2 \\
\text { SIGMA }\end{array}$ \\
\hline Phum Snay Burial 4 (2001) & NZA22375 & $2132 \pm 30$ в.р. & 207 то 53 в.С. \\
\hline Phum Snay Burial 6 (2003) & NZA22376 & $1856 \pm 30$ в.P. & A.D. 75 то 239 \\
\hline Phum Krosaing Thmei (2004) & & $1992 \pm 28$ YRS B.P. & 48 в.С. то 74 \\
\hline Phum Krosaing Thmei (2004) & & $1891 \pm 32$ YRS B.P. & A.D. 57 то 226 \\
\hline
\end{tabular}


to 53 B.C. $(2 \sigma)$ and the burials excavated during the 2003 season provided dates of A.D. 75 to $239(2 \sigma)$. The prehistoric site, Phum Krosaing Thmei, about $1 \mathrm{~km}$ away on the other side of the Preah Net Prey River, contained burials similar to those found at Phum Snay. Phum Krosaing Thmei provided three calibrated radiocarbon dates: A.D. 57 to $226(2 \sigma), 48$ B.C. to A.D. $74(2 \sigma)$, and 51 B.C. to A.D. $128(2 \sigma)$ (Sok pers. comm.).

\section{THE 2OOI EXCAVATION}

An area to the east of the access road into Phum Snay was selected for excavation in January 2001 because it was relatively undisturbed by looters (Fig. 3). Few artifacts were recovered in the upper layers except eroded potsherds, a spindle whorl, and a long, orange glass bead. Layer 2 revealed greater amounts of potsherds, a projectile point, and a carnelian bead. Some ash-glazed and iron-glazed stonewares were also found. There was an increase in the amount of faunal material and in the number of features, especially postholes filled with red sand.

The first interment encountered (B1-'01) was a disturbed adult burial. This burial consisted of a few fragmented bones probably belonging to an older male. A burial was uncovered on the northwestern side of the unit abutting a rock formation found in Layer 3. Burial 5-'01 was a well-preserved and articulated child burial. The infant was interred with a set of ivory bangles on each arm and bronze anklets on each leg. Four pots were broken at the feet of the infant and some glass beads were recovered from the thoracic area.

Another burial was recovered at the western baulk in Layer 3. Burial 8-'01 lay atop the natural substrate and comprised the lower half of an articulated adult skeleton belonging to a woman between 25 and 30 years of age at the time of her death.

More human bone was encountered in the upper spits of Layer 3. Burial 3-'01 was found to be an incomplete, disturbed elderly adult burial situated in clean sand. No artifacts were found in association with the burial.

Another disturbed and fragmentary adult burial (B4-'01) was also situated in the upper spits of Layer 3. No artifacts were found in association with the burial.

In Layer 3, a large pot was discovered in association with human remains (B7'01). The semiarticulated remains of an adult were found at a range of depths.

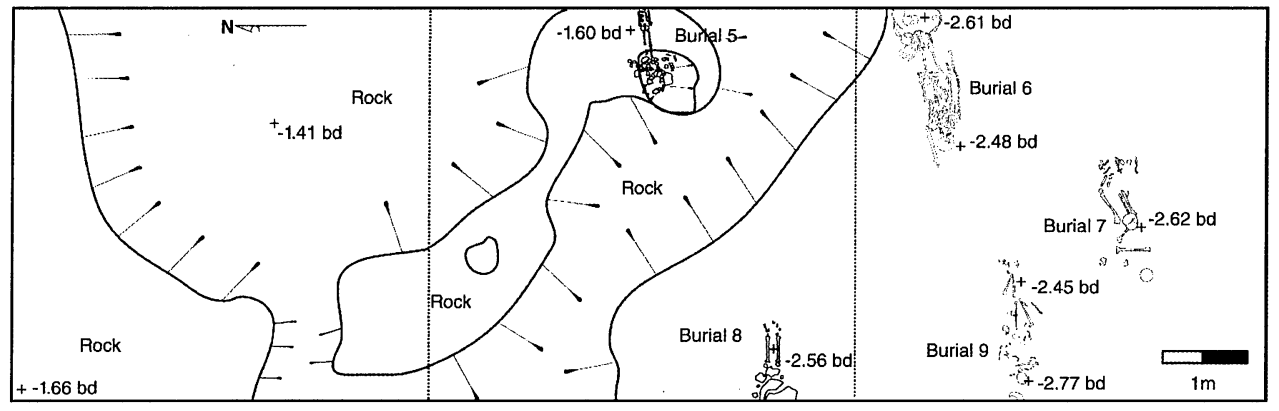

Fig. 3. Area excavated during 2001 showing burial locations. 
There were three broken but complete pottery vessels found in association with Burial 7-'01, as well as ten spindle whorls and some bronze fragments.

Burial 6-'01 was discovered in Layer 3:5 at the interface with the natural substrate. The grave abutted the natural rock formation that covered almost half of the excavated area. This burial comprised the articulated remains of an adult in excellent condition. All bones were represented, although a few were not complete. Burial 6-'01 was found in association with a number of artifacts. The skull was adorned with a green glass earring of considerable size. At the neck, the individual had a large sun bear (Ursus malayanus) canine that bore no evidence as to the method of suspension. Glass beads were found scattered in the thoracic area. Two ivory bangles were associated with the burial, and an unidentifiable bronze object was found clasped in the left hand. This hand also bore a number of bronze finger rings. To the right of the burial, an iron sword was found. Another unidentifiable iron implement, possibly a weapon, was found at the shoulder. A cache of iron projectile points was recovered at the feet, as were four ceramic vessels.

A final burial (B9-'01) was encountered at the interface of Layer 3 and the natural substrate. This burial was considerably disturbed and lay below the water level of the site. Burial 9-'01 comprised a semiarticulated adult skeleton in good condition. The artifacts recovered were found in a disturbed state, mixed with the human remains. One spindle whorl and a whole pot were recovered. Bronze rings were found on the left hand and one ring was found loose in the matrix with a bronze bangle. Several black glass beads were recovered from the area around the bones. The faunal remains in the burial will be discussed below.

\section{THE 2003 EXCAVATION}

Phum Snay underwent further scientific investigation during the early months of 2003 (Fig. 4). The excavated area was selected of necessity as looting had destroyed much of the site. A $12 \times 4 \mathrm{~m}$ unit was demarcated in the middle of the village, to the south of the schoolhouse. The excavated area was divided into three equal $4 \times 4 \mathrm{~m}$ units, labeled $\mathrm{A}$ through $\mathrm{C}$. The trench ran north to south, with Unit A being northernmost. A datum was established on the west corner of school's porch. To the west and east of Unit A, two more $4 \times 4 \mathrm{~m}$ units were excavated, labeled Unit A/west and Unit A/east. Unit C also was extended to the east (a $2 \times 2 \mathrm{~m}$ unit labeled Unit C/east) and west (Unit C/west, an offset $4 \times 4 \mathrm{~m}$ unit).

The site was excavated using the same techniques employed in 2001 , by $10-\mathrm{cm}$ spits. Assigning a new layer number denoted major changes in the color of the stratigraphy. The uppermost deposits were labeled Layer 1, in which there were just 3 spits; Layer 2 contained 6 spits; Layer 3 contained 12 spits.

The first three spits of Layer 1 comprised overburden, and a great many modern artifacts were contained within these layers. The soil color changed markedly c. 15-20 cm below datum to grayish brown, marking the beginning of Layer 2 . Prehistoric pottery began to appear in the upper spits of this layer. Clusters of pots were encountered at c. $60 \mathrm{~cm}$ below datum.

At $80-115 \mathrm{~cm}$ below datum there was another change in the soil color, marking the advent of Layer 3. A concentration of pottery was encountered at $78 \mathrm{~cm}$ 


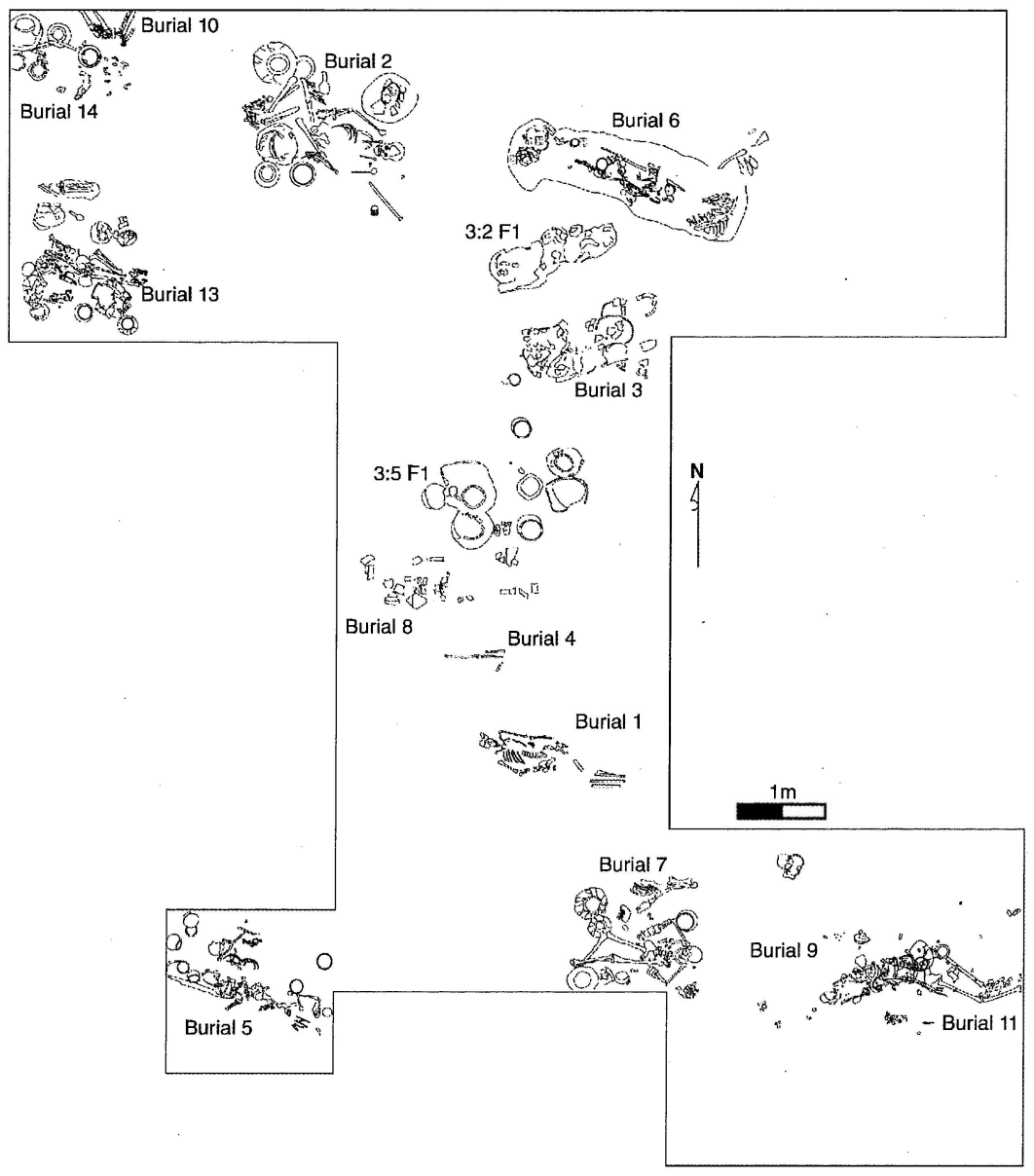

Fig. 4. Area excavated during 2003 showing burial locations.

below datum in Unit A (3:1 Feature 1). No human remains were recovered, but it is possible that this feature represents an interment as it contained a number of artifacts. These included four ceramic vessels, a carnelian bead, and a glass bead, as well as an unidentified iron object. Adjacent to this feature, another concentration of artifacts was found on the border of Unit A and B. This was originally labeled as a feature but was found to represent a burial after the discovery of an adult skull of indeterminate sex. No other skeletal elements were present. This interment contained two spindle whorls, broken pots, a clay pellet, and an unidentified iron object. Most of the pottery was piled atop where the subcranial remains would have been. Below these artifacts were found iron bangles and rings, a whole pot and sherds, two iron tools, a bronze artifact, a clay bracelet fragment, and a lithic flake. An iron object was found above the head.

Burial 1-'03 was encountered in Layer 3:2, in the center of Unit C, with the feet to the east. The individual was a middle-aged/old female at death. The burial contained two bronze artifacts and a glass bead. 
Burial 2-'03 was encountered in Layer 3:4 in Unit A. Only the head and shoulders of the burial appeared in the unit. The balance of the interment was uncovered during the excavation of Unit A/west. The burial contained 20 artifacts, including pottery, two carnelian beads, an iron dagger, a smaller iron blade, an iron spearhead, projectile points, iron bangles, bronze bells, a Sun Bear canine, and several unidentified iron objects. The head of this middle-aged or older male was orientated to the east.

Burial 3-'03, an adult of indeterminate sex, was found lying between Units A and $\mathrm{B}$. The burial is incomplete, but a cranium was recovered. The grave goods included spindle whorls and ceramics. There were some unidentifiable iron objects in the grave as well as bronze bangles and some bronze rings, a clay bracelet, and a stone flake.

In Unit B, Layer 3:3, Feature 1, a scatter of potsherds extended from the west baulk, which also contained an agate bead and a glass bead.

Burial 4-'03 was discovered in Layer 3:3 Unit B at $105 \mathrm{~cm}$ below datum. The burial comprised a femur and a tibia, with the head orientated to the east. There were no artifacts in the grave and the sex of this adult was not established.

Burial 5-'03 was first encountered in Unit C, Layer 3:4, with the discovery of bovid bones and human tarsal bones. The rest of the burial, which seemed to be disturbed by the water table, was uncovered during the excavation of Unit $\mathrm{C} /$ east. The burial contained the remains of a young adult male who was interred with ten ceramic vessels, bronze bells, bone bangles, an iron bangle, bronze finger rings, an unidentified iron artifact, an iron sickle, and an epaulette made from a ceramic potsherd. There were also the remains of wooden arrow shafts and associated iron points in the grave and a large iron sword that was over a meter in length.

Burial 6-'03 was encountered in Layer 2 in Unit A along the east baulk. The remainder of the burial, comprising the skull and some animal bones, was uncovered during the excavation of the adjacent unit, A/east. The grave was that of a middle-aged male with his head orientated east. The individual was buried with bovid bones above the head and at the feet. The grave cut was lined with a very hard substance, probably resin. Inside the grave, rice was sprinkled and the body put on top. This individual was buried with many artifacts, including ten pots, a clay pellet, bronze bells, bronze finger rings, two iron sickles, an iron axe, a bronze bangle, two bone bangles, an ivory bangle, several unidentified iron objects, probably including projectile points, and an iron sword.

Burial 7-'03 was encountered in Unit C near the south baulk and continued into the east baulk where the head and shoulders were located. The complete burial of a middle-aged adult female was eventually recovered with the excavation of Unit C/east. This individual was buried with over 20 artifacts, including pottery, spindle whorls, bronze rings, glass beads, iron projectile points, a glass earring, and several unidentifiable bronze and iron artifacts. There was also an iron torque around the neck of this individual.

Burial 8-'03 was uncovered in Unit B in Layer 3:3. The burial comprised a long scatter of potsherds that extended across most of the unit from west to east. A small fragment of long bone was found, but this did not allow a determination of the age or sex of the individual in the burial.

In Layer 3:5, a feature (1) was encountered that included two infant teeth. The 
burial was quite rich, including seven ceramic vessels, an iron axe, caches of iron projectile points, an iron torque, and a finger ring fragment.

After the completion of the initial $12 \times 4 \mathrm{~m}$ area, the excavation was expanded. Two $4 \times 4 \mathrm{~m}$ units were added on either side of Unit A, thereby allowing the complete recovery of Burials 2 and 6 . A further $4 \times 4 \mathrm{~m}$ unit was added to the east of Unit C, slightly offset in order to recover Burial 7 , and a small $2 \times 2 \mathrm{~m}$ unit was dug to the west of Unit $\mathrm{C}$ to recover Burial 5 .

Burial 9-'03, containing a possible adult female, was discovered in Unit C/east in 2:2. A large amount of pottery covered the body, and many small glass beads were recovered-some from inside a Phimai black bowl. The burial surrendered over 30 carnelian beads from the waist and a bronze bowl that was attached to the right side of the skull. Other items included ceramic vessels, spindle whorls, finger rings of bronze, glass beads, iron tools, and bronze bangles. The feet of this individual were oriented to the east.

Burial 10-'03 was located in Unit A/west along the north baulk. The burial consisted of partial femur, tibiae, and fibula extending from the baulk. One iron artifact and a whole pot were recovered.

Burial 11-'03 was discovered directly below Burial 9, $92 \mathrm{~cm}$ below datum. Much of the burial was recoverable, but the bones were in poor condition. The feet remain in the east baulk of Unit $\mathrm{C} /$ west. The burial was relatively poor, containing a middle-aged/old adult of unknown sex. The bones lay underneath a deposit of animal bone, probably a grave offering. Other items in the grave included an iron bangle, spindle whorls, and a pot.

An adolescent skeleton was found in Burial 12-'03 located along the west baulk of Unit C/east at approximately $90 \mathrm{~cm}$ below datum. The burial ran eastwest and included a single artifact-a small iron sword-and some poorly preserved human bone.

Burial 13-'03 was recovered in Unit A/west at $146 \mathrm{~cm}$ below datum. The young adult female was buried with several ceramic vessels, spindle whorls, and red ochre. Other burial goods included unidentified iron artifacts, a ceramic epaulette with miniature replicas of buffalo horns fashioned from iron, an iron torque around the neck, and three bronze bangles. A bone bangle and three groups of finger rings on both hands were also found. The woman was buried on her back with the knees originally flexed upward; the bones had collapsed so that the tibia and femur lay beside/on top of one another.

The grave cut of Burial 14-'03, containing an adult (possibly female) skeleton, appears to have been lined with bamboo. The base of the burial was very hard, similar to Burial 6, and may have been coated with resin. Found at about $145 \mathrm{~cm}$ below datum, this burial contained complete pots, a bangle on the right arm, finger rings, and three unidentified iron artifacts.

One of the few nonburial features (3:2 Feature 2) encountered in the prehistoric levels included the remains of a hearth in Unit A/west at $80 \mathrm{~cm}$ below datum. This hearth comprised a darkened area along the north baulk from which two large bamboo poles extended to the south. In section it appeared that the hearth pit was lined with bamboo and was dug to a depth of $50 \mathrm{~cm}$.

The entire area was excavated to a depth of $190 \mathrm{~cm}$ below datum, where groundwater was encountered. The soil at this depth was a fine, hard sand containing no cultural remains. A concreted and mineralized material, similar to that 
encountered during the 2001 excavation, was found in Unit A/east. This material is impossible to excavate and covered about half of the western portion of the unit at a depth of 135-140 cm below datum.

Analysis of the material recovered from Phum Snay is ongoing. The burial ceramics are undergoing conservation and the remaining artifacts are currently under analysis. Organic materials from the site have as of yet not rendered samples suitable for radiocarbon age determination, but it is likely that the site dates to the early centuries of the first millennium.

The preliminary results of the excavation indicate that Phum Snay represents one of the more important prehistoric sites in Cambodia and is certainly significant in regional terms as well. It is comparable with Iron Age sites found in Thailand, especially those on the Khorat Plateau-but with important differences. The individuals interred at Phum Snay appear to have more weaponry than do those buried at the sites in Thailand. It is possible that the proximity of the site to the later Angkorian center is of significance.

\section{THE FAUNAL REMAINS}

The faunal remains recovered during the excavations detailed above were measured according to international standards (von den Driesch 1976/1999). It reveals broad similarities between Phum Snay and other contemporaneous sites in Southeast Asia and provides us with an insight into the economy and geography of the site. All faunal remains discovered during the excavation were catalogued with provenance information and examined in the laboratory at the Faculty of Archaeology of the Royal University of Fine Arts in Phnom Penh, Cambodia.

Bovine species from prehistoric sites in Southeast Asia often comprise gaur (Bibos gaurus), banteng (Bibos javanicus), kouprey (Bos sauveli), domestic or water buffalo (Bubalus arnee f. bubalis), Bali cattle (domestic form of banteng), and cattle (Bos primigenius f. taurus). At present, gaur and kouprey still live in a small area of northern Cambodia; kouprey has been recorded since 1975 (Corbet and Hill 1992). Both taxa belong to the heavily endangered fauna of Cambodia. Higham (1975:8ff.), in his analysis of the faunal remains from Non Nok Tha (Thailand), studied the osteological differences of distinct skeletal parts of these large bovids. Using Higham's metric data for comparison, there are no significant difficulties in distinguishing the large bovid long bones from Phum Snay, because only two species are present in the assemblage. The water buffalo is characterized by its heavy and sturdy metapodials and phalanges (Higham 1975: Fig. 8). If an entire leg is present, then the other bones are easily identifiable and served as material for comparison for the more incomplete bones. In contrast, cattle bones have a very distinct shape in being much more slender (Table 2). The foot bones closely resemble those of a zebu. They are smaller than bones of Bibos described by Higham (1975:121 ff.). However, it is possible that the nonmeasurable bovid bone fragments in the nonburial assemblage of Phum Snay may belong to the Bibos forms or the kouprey, particularly when one takes into account the apparent prevalence of hunting among the site's inhabitants in prehistory.

During the identification work, three different size categories of deer, family Cervidae, were recognized. Larger bone elements exhibit typical features of the skeleton of Cervus, particularly in the foot bones. The bones are not as large as in 
Table 2. Measurements of Bones of Large Bovids

\begin{tabular}{|c|c|c|c|c|c|c|}
\hline SCAPULA & $\begin{array}{c}\text { C/BURIAL } \\
5\end{array}$ & $\begin{array}{c}\text { AE/BURIAL } \\
6\end{array}$ & $\begin{array}{c}\text { C/BURIAL } \\
5\end{array}$ & $\begin{array}{c}\mathrm{AW} / \mathrm{BURIAL} \\
\mathrm{I} 3\end{array}$ & $\begin{array}{c}\text { CE/BURIAL } \\
7\end{array}$ & $\begin{array}{c}\text { AE/BURIAL } \\
6\end{array}$ \\
\hline $\mathrm{KLC}$ & - & 70 & 62.5 & 45 & 39 & 57.5 \\
\hline GLP & 82 & 92.5 & 90 & 60 & 57 & 86.5 \\
\hline LG & 69 & 76 & 70 & 52.3 & 49.5 & 66.5 \\
\hline BG & 52 & 61 & 53.5 & 43 & 41.5 & 56.5 \\
\hline Species/Sex & B.b./f & B.b./m & B.b./m & B.t./f, juv. & B.t./f, juv. & B.b./f \\
\hline
\end{tabular}

Note: Abbreviations of measurements following von den Driesch 1976/1999: B.b. = buffalo; B.t. $=$ cattle; $\mathrm{f}=$ female; $\mathrm{m}=$ male; juv. = juvenile.

\begin{tabular}{|c|c|c|c|c|}
\hline HUMERUS & C/BURIAL 5 & C/BURIAL 5 & CE/BURIAL 7 & AE/BURIAL 6 \\
\hline GL & 310 & - & - & 320 \\
\hline LC & 270 & - & - & 285 \\
\hline $\mathrm{Bp}$ & 102 & - & - & 100 \\
\hline KD & 43 & - & - & 43.2 \\
\hline BT & 99.5 & 83 & 63.5 & 92.5 \\
\hline Species/Sex & B.b./m & B.b./f & B.t./f & B.b./m \\
\hline
\end{tabular}

\begin{tabular}{|c|c|c|c|c|}
\hline RADIUS & C/BURIAL 5 & CE/BURIAL 7 & AE/BURIAL 6 & AE/BURIAL 6 \\
\hline GL & - & - & (340) & 308 \\
\hline $\mathrm{Bp}$ & 98 & 70 & 101 & 90 \\
\hline BFp & 92 & 64 & 91.5 & 82.5 \\
\hline KD & 49 & - & 50 & - \\
\hline $\mathrm{Bd}$ & - & - & 90 & - \\
\hline Species/Sex & B.b./m & B.t./f & B.b./m & B.b./f \\
\hline
\end{tabular}

\begin{tabular}{|c|c|c|c|c|c|}
\hline METACARPUS & C/BURIAL 5 & C/BURIAL 5 & CE/BURIAL 7 & AE/BURIAL 6 & AE/BURIAL 6 \\
\hline Gl & - & - & 185 & - & 191 \\
\hline$B p$ & 65.5 & - & 49.5 & 76.5 & 68.5 \\
\hline $\mathrm{Tp}$ & 41 & - & - & 46 & 43.4 \\
\hline KD & - & - & 25 & - & - \\
\hline $\mathrm{Bd}$ & - & 71.2 & 50 & 81 & 74.1 \\
\hline Species/Sex & B.b./f & B.b./f & B.t./f & B.b./m & B.b./f \\
\hline TIBIA & CE/BURIAL 3:I & & & & \\
\hline $\mathrm{Bd}$ & 67.5 & & & & \\
\hline $\mathrm{Td}$ & 55 & & & & \\
\hline Species & Large bovid & & & & \\
\hline TALUS & C/BURIAL $3: 3$ & C/BURIAL $3: 2$ & & & \\
\hline GL1 & 75.5 & & & & \\
\hline GLm & 69 & 63.2 & & & \\
\hline T1 & 42 & & & & \\
\hline $\mathrm{Bd}$ & 51.2 & & & & \\
\hline Species & B.b. & B.t. & & & \\
\hline
\end{tabular}


TABle 2 (Continued)

\begin{tabular}{lccccccc}
\hline PHALANX I & $\begin{array}{c}\text { C/BURIAL } \\
\text { L5 }\end{array}$ & $\begin{array}{c}\text { C/BURIAL } \\
\text { L5 }\end{array}$ & $\begin{array}{c}\text { C/BURIAL } \\
\text { L5 }\end{array}$ & $\begin{array}{c}\text { C/BURIAL } \\
\text { L5 }\end{array}$ & $\begin{array}{c}\text { CE/BURIAL } \\
\text { L7 }\end{array}$ & $\begin{array}{c}\text { AE/BURIAL } \\
\text { L6 }\end{array}$ & $\begin{array}{c}\text { AE/BURIAL } \\
\text { L6 }\end{array}$ \\
\hline GLpe & 69 & 69.5 & 66.5 & 65 & 53 & 70 & 69 \\
Bp & 43 & 41.5 & 37.5 & 36.3 & 25 & 42.5 & - \\
KD & 35 & 35 & 32 & 31.5 & 19 & 38.5 & - \\
Bd & 37 & 38 & 34 & 33.5 & 24 & 40 & 38 \\
Ant./post. & ant., & ant., & ant., & ant., & ant. & ant., & ant., \\
& lateral & medial & lateral & medial & & lateral & medial \\
Species/Sex & B.b./m & B.b./m & B.b./f & B.b./f & B.t./f & B.b./m & B.b./m \\
\hline
\end{tabular}

\begin{tabular}{lcclc}
\hline PhalanX I & AE/Burial 6 & SI/EI & SI/EI & S2/EI \\
\hline GLpe & 65 & 66 & 70 & 83 \\
Bp & 37 & 28 & 32 & 51 \\
KD & 33 & 25 & 29 & 44 \\
Bd & 35 & - & 32.5 & 48 \\
Ant./post. & ant. & post. & post. & post. \\
Species/Sex & B.b./f & B.t./? & B.t./m & B.b./m \\
\hline
\end{tabular}

\begin{tabular}{|c|c|c|c|c|c|c|c|}
\hline PHALANX 2 & $\begin{array}{c}\text { C/BURIAL } \\
5\end{array}$ & $\begin{array}{c}\text { C/BURIAL } \\
5\end{array}$ & $\begin{array}{c}\text { CE/BURIAL } \\
7\end{array}$ & $\begin{array}{c}\text { A/E } \\
3: 5\end{array}$ & $\begin{array}{c}\mathrm{AE} / \mathrm{BURIAL} \\
6\end{array}$ & $\begin{array}{c}\text { AE/BURIAL } \\
6\end{array}$ & $\begin{array}{c}\text { AE/BURIAL } \\
6\end{array}$ \\
\hline GL & 48 & 44 & 34.5 & 49.5 & 50 & 45 & 45.8 \\
\hline$B p$ & 40.5 & 36.5 & 25 & 42 & 42 & 39 & 39 \\
\hline $\mathrm{KD}$ & 32 & 28.2 & 46.5 & 34.5 & 34 & 30 & 29 \\
\hline $\mathrm{Bd}$ & 35 & 29 & 20 & 35.2 & 35.5 & 31.5 & 32 \\
\hline $\begin{array}{l}\text { Ant./post. } \\
\text { Species/Sex }\end{array}$ & $\begin{array}{l}\text { ant., lat. } \\
\text { B.b./m }\end{array}$ & $\begin{array}{l}\text { ant., med. } \\
\text { B.b./f }\end{array}$ & $\begin{array}{l}\text { ant. } \\
\text { B.t./f }\end{array}$ & $\begin{array}{l}\text { ant., lat. } \\
\text { B.b./m }\end{array}$ & $\begin{array}{l}\text { ant., med. } \\
\text { B.b./m }\end{array}$ & $\begin{array}{l}\text { ant., lat. } \\
\text { B.b./f }\end{array}$ & $\begin{array}{l}\text { ant., med. } \\
\text { B.b./f }\end{array}$ \\
\hline
\end{tabular}

\begin{tabular}{llllcc}
\hline PHAlanX 2 & Aw, 3:4 & C, 3:6 & Aw, 3:I & S3EI/BUR.6 & S2EI \\
\hline GL & 63.5 & 45 & 57.5 & 37 & 49 \\
Bp & 45.8 & 34 & 42.8 & 27.8 & 42 \\
KD & 32.6 & - & 32 & - & 30.5 \\
Bd & 38 & - & 34 & - & 32 \\
Ant./post. & post. & ? & post./? & ? & ? \\
Species/Sex & B.b./m & B.t./m & B.b./m & B.t./? & B.b./? \\
\hline
\end{tabular}

the brown antlered deer (Cervus eldi), which measures 107-115 $\mathrm{cm}$ in height at the shoulder (Kurt 1988a:142). The only smaller Cervus species in Cambodia is the Sambar or Indian horse deer (Cervus unicolor). This species' shoulder height varies from 90 to $150 \mathrm{~cm}$. The bones from Phum Snay belong to specimens whose body sizes fall into the lower part of the variation indicated in the literature. The next size group of deer bones fits morphologically with the skeleton of the hog deer (Axis porcinus). Metapodials and phalanges of the hog deer are highly characteristic and unmistakable. Due to a remarkable sexual dimorphism, the size 
variation of the bones is large (Table 3). A third size group of deer consists of very small bones, typical in size and morphology of the Indian or barking deer (Muntiacus muntjak), with a shoulder height of $40-65 \mathrm{~cm}$ (Kurt 1988b). The small dimensions of the bone measurements are distinctive of this species.

Among the fish remains recovered, most predominant species were members of the family Channidae, or snakeheads. The second most common group is catfish, represented by at least four families (Bagridae, Siluridae, Pangasidae, and Clariidae), followed by minnows or carps in the family Cyprinidae. The state of preservation of the fish material made it impossible to identify the major part of the bones to species level. All the fish families mentioned above include several species that have a very similar bone morphology. The reconstruction of the fish lengths was carried out by comparing excavated bones with skeletons of fish of known sizes (Table 4).

\section{RESULTS}

\section{Faunal Remains from Burial Contexts}

Animal bones as burial goods were not encountered in all graves (Table 5). From a total of 23 inhumation burials only 11 contained animal bones. Burials '03/5, '03/6, '03/7, and '03/13 contained the complete forelimbs of artiodactyls, water buffalo, cattle, and pigs. The portions represented included the section from the scapula to the third phalanges. In two instances, ribs and some vertebrae were associated with the limb bones of a cow and a pig, and in one, part of the animal's thorax was also deposited with the forelimbs. Most of the long bones-that is, scapulae, humeri, radii, and metapodials-were broken, resulting in incomplete measurements for these bones (Table 2). All faunal material deposited in these units derives from domestic animals, and all are from forelimbs. Only the bones of adult buffalo and cattle were found in burials, whereas pig bones belonged exclusively to young animals. Only female cattle were placed as offerings in the Phum Snay burials. In contrast, both sexes of buffalo have been identified. There seems to be a correlation between the sex of the deceased individual and the sex and species of animal placed in the grave. Most males were interred with the legs of buffalos (and pigs) and females with those of cattle (and pigs). It is possible that chickens were also chosen for the grave cult as evidenced by a left humerus in Burial '03/7.

It is also apparent that only the left side of the animal was placed in the grave as burial offering. The animal remains were found on either side of the body, but most interments had the faunal remains placed to the left of the body. Burial '03/ 5 contained buffalo bones to the north and left side of the feet. In Burial '03/6 the animal bones were deposited on the right side of the deceased, both above the head and at the feet. The animal bones in Burial '03/7 were also on the right side of the human remains, whereas Burial '03/13 had the cattle bones deposited on the left side to the north of the human remains.

In Burial '03/2, the canine of a large carnivore was discovered in the thoracic area of the human skeleton. It is not included in Table 2 because we consider the tooth as an amulet or a pendant similar to the canine teeth from Burial 27 of Noen U-Loke in Thailand (Higham and Thosarat 1998: Fig. 250). It appears to 
Table 3. Measurements of Deer Bones

\begin{tabular}{lcccccccc}
\hline MAXILlA & C, 3:4 & C, 3:2 & AE, 2:6 & AW, 3:2 & SIEI, 2:3 & SIEI, 2:5 & SIEI, 2:5 & S2EI, 2:5 \\
\hline Species & A.p. & A.p. & M.m. & A.p. & A.p. & A.p. & A.p. & A.p. \\
LMR & - & 47 & - & - & - & - & 48 & -17.4 \\
LM $^{3}$ & 16.5 & - & 15.5 & 17 & 18.5 & 16.8 & 17.8 & 17.4 \\
BM $^{3}$ & - & - & 11.5 & 12.2 & 15.3 & 14 & 14.5 & 13 \\
\hline
\end{tabular}

Note: C.u. = Cervus unicolor; A.p. = Axis porcinus; M.m. = Muntiacus muntjak.

\begin{tabular}{lcccccc}
\hline MANDIBUla & CE, 2:5 & C, 3:6 & CE, 2:6 & SIEI, 2:3 & SIEI, 3:I & SIEI \\
\hline Species & A.p. & A.p. & $?$ & A.p. & A.p. & C.u. \\
LMR & - & - & - & - & 44.8 & - \\
LM $_{3}$ & 20 & 19 & 25 & 19.5 & 18 & 28 \\
BM $_{3}$ & 8.5 & 10.5 & 9.5 & 9.5 & 9 & 12 \\
\hline
\end{tabular}

\begin{tabular}{lclllllll}
\hline SCAPUla & CE, 3:I & CE, 3:3 & AW, 3:4 & SIEI, 2:5 & SIEI, 3:I & SIEI, 3:I & S2EI, 2:4 & S2EI, 3:I \\
\hline Species & C.u. & A.p. & A.p. & A.p. & A.p. & A.p. & A.p. & A.p. \\
KLC & - & 20.8 & 21.5 & 18.5 & 18.5 & 18.8 & - & 22 \\
GLP & 52 & 42.5 & 35.7 & 34.3 & 36 & 35.7 & 33.5 & 35.7 \\
LG & 40 & 34 & 28 & 28.5 & - & 29 & 28.8 & 38.2 \\
BG & 35.5 & 28 & 24 & 23.2 & - & 26.2 & 23 & 26.8 \\
\hline
\end{tabular}

\begin{tabular}{llllll}
\hline HUMERUS & C, 3:6 & C, 3:4 & SIEI, 2:3 & S2EI, 2:5 & S2EI, 2:5 \\
\hline Species & A.p. & A.p. & A.p. & A.p. & M.m. \\
BT & 37.5 & 33.5 & 35 & 35.5 & 31.2 \\
\hline
\end{tabular}

\begin{tabular}{lcccccc}
\hline RADIUS & C, 3:6 & CE, 2:2 & SIEI, 2:4 & SIEI, 2:5 & S2EI, 2:5 & S2EI, 3:54 \\
\hline Species & A.p. & A.p. & A.p. & A.p. & A.p. & A.p. \\
Bp & 36.5 & - & - & 36.5 & 35.5 & 31 \\
BFp & 35 & - & - & 34.5 & 32 & 30 \\
Bd & - & 35.5 & 28 & - & - & - \\
\hline
\end{tabular}

\begin{tabular}{|c|c|c|c|c|c|c|}
\hline METACARPUS & $\mathrm{CE}, 3: \mathrm{I}$ & $\mathrm{AE}, 3: 5$ & SIEI, $2: 4$ & SIEI, $2: 5$ & S2EI, 3:I & S3EI, 2:S \\
\hline Species & C.u. & A.p. & A.p. & A.p. & A.p. & ? \\
\hline $\mathrm{Bp}$ & 32.5 & - & 21 & - & 23.8 & 30 \\
\hline $\mathrm{Tp}$ & 22 & - & - & - & 16.8 & 20 \\
\hline KD & 19 & - & - & - & - & - \\
\hline $\mathrm{Bd}$ & - & 24 & - & 20.5 & - & - \\
\hline
\end{tabular}


TABle 3 (Continued)

\begin{tabular}{lccc}
\hline FEMUR & S2EI & S2EI, 2:5 & S2EI, 3:2 \\
\hline Species & A.p. & A.p. & A.p. \\
Bp & - & 44 & - \\
TC & - & 20 & 25 \\
Bd & 41 & - & - \\
\hline
\end{tabular}

\begin{tabular}{lccccccc}
\hline TIBIA & AW, 3:3 & SIEI, 2:4 & SIEI, 2:4 & S2EI, 2:5 & S2EI. 2:5 & S2EI, 2:5 & S2EI, 2:3 \\
\hline Species & C.u. & C.u. & A.p. & A.p. & A.p. & A.p. & ? \\
Bp & - & 63 & - & 42.8 & - & 44 & - \\
$\mathrm{Tp}$ & - & - & - & 40 & - & - & - \\
$\mathrm{Bd}$ & 36.5 & - & 25.5 & - & 27 & - & 32 \\
$\mathrm{Td}$ & 32.5 & & - & - & - & - & - \\
\hline
\end{tabular}

\begin{tabular}{lccccccc}
\hline TALUS & AW, 3:4 & CE, 2:2 & CW, 3:4 & C, 3:3 & CE, 2:6 & SIEI, 2:2 & S2EI, 2:5 \\
\hline Species & $?$ & C.u. & A.p. & $?$ & A.p. & A.p. & A.p. \\
GLl & - & 43 & - & - & 37 & - & 32 \\
GLm & - & - & - & 36.5 & 34.5 & 31.8 & 29.6 \\
Tl & - & 24 & - & - & 21 & 18.5 & 16.7 \\
Bd & 26.5 & 26 & 22.6 & - & - & 23.5 & 19.2 \\
\hline
\end{tabular}

\begin{tabular}{lcccc}
\hline CEntroquartale & C, 3:5 & CE, 2:2 & S2EI, 2:5 & S3EI, 3:2 \\
\hline Species & A.p. & A.p. & A.p. & C.u. \\
GB & 30.2 & 33.5 & 25.5 & 47 \\
\hline CALCANEUS & S2EI, 3:I & & & \\
\hline Species & A.p. & & & \\
GL & 68 & & & \\
GB & 25 & & & \\
\hline
\end{tabular}

\begin{tabular}{lccccccc}
\hline Metatarsus & Siei, 2:3 & Siei, 2:3 & Siei, 2:3 & Siei, 2:3 & Siei, 2:3 & S2Ei, 2:4 & S2Ei, 2:4 \\
\hline Species & A.p. & A.p. & C.u. & A.p. & M.m. & A.p. & A.p. \\
Bp & - & - & - & - & - & 21.5 & - \\
Tp & - & - & - & - & - & 22.8 & - \\
Bd & 27 & 25 & 42 & 29.5 & 21 & 29.5 & 25.5 \\
Td & 20.3 & - & - & 22 & - & 21.5 & - \\
\hline
\end{tabular}

(Continued) 
TABle 3 (Continued)

\begin{tabular}{lcccccccc}
\hline PHALANX I & AW, 3:2 & AW, 3:4 & CE, 2:6 & SIEI, 2:2 & SIEI, 2:3 & SIEI, 2:4 & S2EI, 2:4 & S2EI, 2:4 \\
\hline Species & A.p. & C.u. & A.p. & A.p. & A.p. & A.p. & A.p. & A.p. \\
Glpe & 43 & - & 39.2 & 37 & 37 & 39.6 & 36 & 34.8 \\
Bp & - & - & 14 & 12.2 & 12.7 & 13.5 & 12.2 & 11.6 \\
KD & - & 16.5 & 11 & 8 & 10 & 9.2 & 10 & 9.2 \\
Bd & 12 & 19.2 & 12 & 10.5 & - & 11.2 & 11.2 & 10 \\
\hline
\end{tabular}

\begin{tabular}{lccccccc}
\hline PHAlANX I & S2EI, 2:5 & S2EI, 2:5 & S.EI & S2EI, 3:I & PHALANX 2 & S2EI, 2:5 & S2EI, 2:5 \\
\hline Species & A.p. & A.p. & M.m. & A.p. & Species & A.p. & A.p. \\
Glpe & 42.5 & 36.9 & 32.5 & - & GL & 27.3 & 25.7 \\
Bp & 15 & 12 & 11.1 & - & Bp & 12 & 11 \\
KD & 10.9 & 8.7 & 9 & - & KD & 8.3 & 8.5 \\
Bd & 12.5 & 10.8 & 10.5 & 13.5 & Bd & 9.5 & 9.5 \\
\hline
\end{tabular}

be the upper canine of a Sun bear, Ursus malayanus, the only large bear species found in Cambodia (Corbet and Hill 1992:192).

The clear differentiation between the sex of the interred and the type and portion of animal remains buried with them was not as clear in the portion of the cemetery excavated during 2001 . Burial ' $01 / 6$ yielded the left hind foot (metatarsus and phalanges) of a small adult cow and Burial '01/9 the horn-core of a male buffalo. Domet (pers. comm.), who has examined the human bones, found that the skeleton from Burial '01/6 was a male based on the analysis of the pelvis. Whereas it seems clear that portions of buffalo were deposited in male burials and cow in women's burials in the area of Phum Snay excavated during 2003, this is not the case in the area excavated in 2001. It should be noted that there were other differences in the separate areas of the cemetery, including the vessel morphology and the presence of more military paraphernalia in the area excavated during 2003. This may represent diachronic change, with the remains in the area excavated during 2003 appearing to have been deposited at a later date, c. A.D. $75-239(2 \sigma)$.

Fish remains originating from graves are listed separately (Table 6). The majority of the fish bones from this context consist of snakeheads (Genus Channa). It is noteworthy that three of the fish bone assemblages were found inside pots. In all burials, fish bones represent more than one individual of its species.

\section{Faunal Remains from Nonburial Contexts}

The animal bones found in nonburial contexts probably represent the remains of domestic activity. Many of the bones are fragmented and bear chop and cut marks and none-except for a partial skeleton of a dog (see Table 7) - belong to a single animal.

The nonburial assemblage is much larger than the assemblage of fauna from interments (Tables 7 and 8). The nonburial faunal assemblage comprises domestic animals, a variety of wild mammals and reptiles, at least one wild bird species, fish, 
Table 4. Size Variation of Fish from Nonburial Context

\begin{tabular}{|c|c|c|c|}
\hline $\begin{array}{l}\text { FISH } \\
\text { SPECIES/GENUS/FAMILY }\end{array}$ & $\mathrm{N}$ & MNI & RECONSTRUCTION OF TOTAL LENGTHS IN CM \\
\hline Chitala sp. & 4 & 3 & $60-65$ \\
\hline Notopterus notopterus & 1 & 1 & 35 \\
\hline Cyprinidae & 29 & 7 & $30(2) ; 40(2) ; 60(2) ; 70$ \\
\hline Cyclocheilichthys sp. & 11 & 9 & $30-35(2) ; 60(6) ; 80$ \\
\hline Mystus sp. & 58 & 20 & $\begin{array}{l}20(2) ; 30-35(3) ; 40-45(4) ; 50(3) ; 60(3) ; 70 \\
\quad 75-80 .(3) ; 100\end{array}$ \\
\hline Wallago attu & 28 & 15 & $\begin{array}{l}10-12 ; 20-25(3) ; 35-40(2) ; 50(2) ; 60-65(3) ; \\
\quad 80-85(4)\end{array}$ \\
\hline Pangasidae & 52 & 21 & $\begin{array}{l}40(5) ; 50(2) ; 60(4) ; 70-75 ; 80-85(2) \\
\quad 100(4) ; 120(2) ; 200\end{array}$ \\
\hline Clarias sp. & 20 & 10 & $8(2) ; 10-15(2) ; 20-25(4) ; 35-40(2)$ \\
\hline Monopterus albus & 1 & 1 & 90 \\
\hline Mastacembelus sp. & 1 & 1 & $60-65$ \\
\hline Pristolepis fasciatus & 3 & 1 & 20 \\
\hline Anabantidae & 22 & 5 & $8-10(2) ; 12-15(2) ; 20$ \\
\hline Trichogaster pectoralis & 1 & 1 & 20 \\
\hline Channa sp. & 129 & 26 & $\begin{array}{l}10(2) ; 15(4) ; 20-25(5) ; 30 ; 35-40(5) ; 50(3) ; \\
\quad 60(2) ; 70-75(3) ; 100\end{array}$ \\
\hline
\end{tabular}

and two species of mollusks. Compared with the overall number of bones (a total of 2675 specimens including the unidentified bones), there is a wide variety of identified taxa. Regrettably, the preservation of the bones was poor (especially for mammals and reptiles), resulting in a large amount of bone that was unidentifiable.

All pig bones found in burial and nonburial contexts derive from young and slender animals (Table 9). The archaeological specimens have longer legs and were probably less robust than the pig breeds kept in Cambodia today.

The incomplete skeleton of a dog was recovered during the 2001 excavation. The dog was medium-sized with a reconstructed shoulder height of approximately $60 \mathrm{~cm}$ (calculated according to Harcourt 1974). Domestic fowl include chickens and ducks. Chickens were small-only slightly larger than their wild ancestor, the red jungle fowl, Gallus gallus.

A remarkable characteristic of the faunal assemblage listed in Table 5 is the high proportion of bones belonging to wild animal species. This is in accordance with the results of Higham's (1975:134) faunal analysis of animal bones from the cemetery at Non Nok Tha, located on the Khorat Plateau in northeastern Thailand. In our sample, a total of 295 bones of domestic animals were identified, while 521 bones of wild animals were recognized, including 12 fragments of a freshwater shellfish and 2 fragments of a freshwater gastropod. Evidence for the hunting of gaur (Bibos gaur) and banteng (Bibos javanicus) is absent (see above).

As noted above, the species list of wild fauna is long given the relatively small sample size. It is, however, poorer than the faunal spectrum found in early prehistoric Ban Chang and at other sites in northeastern Thailand (Higham and Kijngam 1979, 1982). More than 50 percent of the identified bones of wild animals derive from deer of at least three species: the larger Sambar, the medium-sized 
Table 5. Phum Snay: Species and Skeletal Parts of Mammals Identified in Burials

\begin{tabular}{|c|c|c|c|c|c|}
\hline SPECIES & $\begin{array}{l}\text { BURIAL } 2, \\
\text { UNIT A }\end{array}$ & & $\begin{array}{l}\text { BURIAL } 5, \\
\text { UNIT C }\end{array}$ & $\begin{array}{l}\text { BURIAL } 6 \\
\text { UNIT A }\end{array}$ & $\begin{array}{l}\text { BURIAL } 7, \\
\text { UNIT C }\end{array}$ \\
\hline Buffalo & - & \multicolumn{2}{|c|}{2 left forelimbs } & $\begin{array}{l}2 \text { left forelimbs, } \\
10 \text { ribs }\end{array}$ & - \\
\hline Cattle & - & \multicolumn{2}{|r|}{ - } & - & $\begin{array}{l}1 \text { left forelimb, } \\
5 \text { ribs, } \\
3 \text { thoracic } \\
\text { vertebrae }\end{array}$ \\
\hline $\begin{array}{l}\text { Unidentified } \\
\text { large bovids }\end{array}$ & - & \multicolumn{2}{|l|}{10} & - & - \\
\hline Pig & mandible & \multicolumn{2}{|r|}{ - } & 2 left forelimbs & $\begin{array}{l}1 \text { left forelimb, } \\
5 \text { ribs }\end{array}$ \\
\hline Chicken & - & \multicolumn{2}{|r|}{ - } & - & left humerus \\
\hline $\begin{array}{l}\text { Age and sex } \\
\text { of animal(s) }\end{array}$ & $\begin{array}{l}\text { fragment from } \\
\text { inside pot }\end{array}$ & \multicolumn{2}{|c|}{$\begin{array}{l}\text { buffalo: } 1 \text { adult male, } \\
1 \text { adult female }\end{array}$} & $\begin{array}{l}\text { buffalo: } 1 \text { adult male, } \\
1 \text { adult female } \\
\text { pig: } 1 \text { subadult, } \\
1 \text { juvenile }\end{array}$ & $\begin{array}{l}\text { cattle: adult } \\
\text { female } \\
\text { pig: infantile }\end{array}$ \\
\hline $\begin{array}{l}\text { Age and sex } \\
\text { of human }\end{array}$ & $?$ & \multicolumn{2}{|c|}{ young adult male } & middle-aged male & $\begin{array}{l}\text { middle-aged } \\
\text { female }\end{array}$ \\
\hline SPECIES & \multicolumn{2}{|l|}{$\begin{array}{l}\text { BURIAL I } 3 \text {, } \\
\text { UNIT A }\end{array}$} & $\begin{array}{c}\text { BURIAL } 3, \\
\text { S3EI }\end{array}$ & $\begin{array}{c}\text { BURIAL } 6, \\
\text { S3EI }\end{array}$ & $\begin{array}{l}\text { BURIAL } 9, \\
\text { S3EI }\end{array}$ \\
\hline Buffalo & \multicolumn{2}{|l|}{ - } & - & - & horn-core \\
\hline Cattle & \multicolumn{2}{|l|}{2 left forelimbs } & - & left hind foot & - \\
\hline $\begin{array}{l}\text { Unidentified } \\
\text { large bovids }\end{array}$ & \multicolumn{2}{|l|}{ - } & - & - & - \\
\hline Pig & \multirow{2}{*}{\multicolumn{2}{|c|}{ - }} & mandible & - & - \\
\hline Chicken & & & - & - & - \\
\hline $\begin{array}{l}\text { Age and sex } \\
\text { of animal(s) }\end{array}$ & \multicolumn{2}{|c|}{2 juvenile females } & $\begin{array}{l}\text { right and left side } \\
\text { from female }\end{array}$ & adult female & adult male \\
\hline $\begin{array}{l}\text { Age and sex } \\
\text { of human }\end{array}$ & \multicolumn{2}{|c|}{ young adult female } & old adult, sex? & young adult male? & adult male \\
\hline
\end{tabular}

Table 6. Phum Snay: Fish Identified in Burials

\begin{tabular}{|c|c|c|c|c|c|c|c|}
\hline $\begin{array}{l}\text { FAMILY/ } \\
\text { GENUS OR } \\
\text { SPECIES }\end{array}$ & $\begin{array}{l}\text { BURIAL } 5 \text {, } \\
\text { UNIT C/W }\end{array}$ & $\begin{array}{l}\text { BURIAL } 6, \\
\text { UNIT A/E }\end{array}$ & $\begin{array}{l}\text { BURIAL } 7 \\
\text { UNIT C/E }\end{array}$ & $\begin{array}{l}\text { BURIAL II, } \\
\text { UNIT C/E }\end{array}$ & $\begin{array}{l}\text { BURIAL I } 4 \text {, } \\
\text { UNIT A/w }\end{array}$ & $\begin{array}{l}\text { BURIAL } S \text {, } \\
\text { UNIT SIEI }\end{array}$ & $\begin{array}{l}\text { BURIAL } 6, \\
\text { UNIT S3EI }\end{array}$ \\
\hline Anabantidae & - & - & - & - & - & - & $\begin{array}{l}N=45 ; \\
M N I=2\end{array}$ \\
\hline Clarias sp. & - & - & & - & $N=1$ & - & - \\
\hline Channa sp. & $\begin{array}{l}\mathrm{N}=2 ; \\
\quad \mathrm{MNI}=2\end{array}$ & - & $\begin{array}{l}\mathrm{N}=55 \\
\quad \mathrm{MNI}=3\end{array}$ & $\mathrm{~N}=1$ & $\begin{array}{l}\mathrm{N}=3 \\
\mathrm{MNI}=2\end{array}$ & - & $\begin{array}{l}\mathrm{N}=40 \\
\quad \mathrm{MNI}=2\end{array}$ \\
\hline $\begin{array}{l}\text { Unidentified } \\
\text { Comment }\end{array}$ & 3 & 2 & $\begin{array}{l}80 \\
\text { inside pot }\end{array}$ & - & $\begin{array}{l}1 \\
\text { inside pot }\end{array}$ & 2 & $\begin{array}{l}150 \\
\text { inside pot }\end{array}$ \\
\hline
\end{tabular}


Table 7. Phum Snay: Species Identified from Locations Other than Burials

\begin{tabular}{|c|c|c|c|c|c|c|c|}
\hline SPECIES & UNIT A & UNIT B & UNIT C & $\begin{array}{l}\text { UNIT } \\
\text { SI/EI }\end{array}$ & $\begin{array}{l}\text { UNIT } \\
\text { S2/EI }\end{array}$ & $\begin{array}{l}\text { UNIT } \\
\mathrm{s}_{3} / \mathrm{EI}\end{array}$ & TOTAL \\
\hline \multicolumn{8}{|l|}{ Domestic: } \\
\hline Buffalo & 4 & 1 & 12 & 12 & 25 & 6 & 60 \\
\hline Cattle & - & - & 8 & 9 & 38 & 10 & 65 \\
\hline Unidentified bovid & 24 & 2 & 28 & 23 & 22 & 11 & 110 \\
\hline Pig & 3 & 1 & 5 & 12 & 15 & 3 & 39 \\
\hline Dog & - & - & 4 & 1 & $1 \mathrm{psk}^{*}+6$ & - & 12 \\
\hline Cat & - & - & - & - & 2 & - & 2 \\
\hline Chicken & - & - & 3 & 1 & 2 & - & 6 \\
\hline Duck & 1 & - & - & - & - & - & 1 \\
\hline Sum domestic & 32 & 4 & 60 & 58 & 111 & 30 & 295 \\
\hline \multicolumn{8}{|l|}{ Wild: } \\
\hline Serow & 1 & - & 4 & 1 & 5 & - & 11 \\
\hline Unident. Cervidae & 9 & 1 & 48 & 63 & 71 & 3 & 195 \\
\hline Sambar & 2 & - & 4 & 4 & 2 & 1 & 13 \\
\hline Hog deer & 10 & - & 14 & 27 & 30 & - & 81 \\
\hline Barking deer & 1 & - & 1 & 4 & 4 & - & 10 \\
\hline Wild boar & - & - & 1 & 1 & - & - & 2 \\
\hline Jungle cat & - & - & 2 & - & - & - & 2 \\
\hline Leopard cat & - & - & - & 1 & - & - & 1 \\
\hline Binturong & - & - & - & - & 1 & - & 1 \\
\hline Sarus crane & 1 & - & - & - & 1 & - & 2 \\
\hline Unidentified bird & - & - & 1 & - & - & - & 1 \\
\hline Black Giant tortoise & - & - & 5 & 45 & 103 & 2 & 155 \\
\hline Painted batagur terrapin & - & - & 2 & - & 23 & - & 25 \\
\hline Softshell turtle & - & - & - & 1 & 1 & - & 2 \\
\hline Monitor & - & - & - & 1 & 1 & 1 & 3 \\
\hline Crocodile & - & - & - & - & 3 & - & 3 \\
\hline Meretrix sp. & 12 & - & - & - & - & - & 12 \\
\hline Pila ampullacea & 2 & - & - & - & - & - & 2 \\
\hline Sum wild & 38 & 1 & 82 & 148 & 245 & 7 & 521 \\
\hline Total identified & 70 & 5 & 142 & 206 & 356 & 37 & 816 \\
\hline Unidentified bones & 104 & - & 300 & 623 & 281 & 62 & 1370 \\
\hline
\end{tabular}

* = partial skeleton

Scientific names:

Domestic: Buffalo $=$ Bubalus arnee f. bubalis; Cattle $=$ Bos primigenius $\mathrm{f}$. taurus; Pig $=$ Sus scrofa $\mathrm{f}$. domestica; $\operatorname{Dog}=$ Canis lupus $\mathrm{f}$. familiaris; Cat $=$ Felis silvestris $\mathrm{f}$. catus; Chicken $=$ Gallus gallus $\mathrm{f}$. domestica; Duck = Anas platyrhynchus f. domestica.

Wild: Serow $=$ Nemorhaedus sumatraensis; Sambar $=$ Cervus unicolor; $\mathrm{Hog}$ deer $=$ Axis porcinus; Barking deer $=$ Muntiacus muntjak; Wild boar $=$ Sus scrofa; Jungle cat $=$ Felis chaus; Leopard cat $=$ Prionailurus bengalensis; Binturong $=$ Arctictis binturong; Sarus crane $=$ Grus antigone; Black Giant tortoise $=$ Testudo nutapundi; Painted batagur terrapin $=$ Callagur borneoensis; Softshell turtle $=$ Trion $y x$ cartilagineus; Monitor $=$ Varanus sp.; Crocodile $=$ Crocodylus sp.

hog deer, and the small barking deer. The Sambar (Cervus unicolor) lives in thick forests and marshland and is often seen to feed in water. Most abundant are remains of the medium-sized hog deer (Axis porcinus). Hog deer prefer dense forests; however, the animals are also observed in clearings, grasslands, and occasionally in wet grasslands. These variations in habitat usually are associated with the time of year and the availability of food. The smallest deer present in the assemblage is the Indian or barking deer. These animals live alone in wide-open spaces 
Table 8. Phum Snay: Fish Identified from Locations Other than Burials

\begin{tabular}{|c|c|c|c|c|c|}
\hline $\begin{array}{l}\text { FAMILY/GENUS } \\
\text { OR SPECIES }\end{array}$ & UNIT B & UNIT C & UNIT SIEI & UNIT S2E2 & $\begin{array}{l}\text { TOTAL } \\
(\mathrm{N})\end{array}$ \\
\hline \multicolumn{6}{|l|}{ Notopteridae: } \\
\hline Chitala sp. & - & - & $N=1$ & $\mathrm{~N}=3 ; \mathrm{MNI}=2$ & 4 \\
\hline Notopterus notopterus & - & - & $\mathrm{N}=1$ & - & 1 \\
\hline Cyprinidae: & - & - & $\mathrm{N}=11 ; \mathrm{MNI}=4$ & $\mathrm{~N}=18 ; \mathrm{MNI}=3$ & 29 \\
\hline Cyclocheilichthys sp. & - & - & $\mathrm{N}=7 ; \mathrm{MNI}=6$ & $\mathrm{~N}=4 ; \mathrm{MNI}=3$ & 11 \\
\hline Bagridae: & - & - & $\mathrm{N}=5 ; \mathrm{MNI}=1$ & - & 5 \\
\hline Mystus sp. & - & - & $\mathrm{N}=28 ; \mathrm{MNI}=10$ & $\mathrm{~N}=30 ; \mathrm{MNI}=12$ & 58 \\
\hline \multicolumn{6}{|l|}{ Siluridae: } \\
\hline Wallago attu & - & - & $\mathrm{N}=14 ; \mathrm{MNI}=8$ & $\mathrm{~N}=14 ; \mathrm{MNI}=7$ & 28 \\
\hline Pangasidae & - & - & $\mathrm{N}=32 ; \mathrm{NMI}=11$ & $\mathrm{~N}=20 ; \mathrm{NMI}=10$ & 52 \\
\hline \multicolumn{6}{|l|}{ Clariidae: } \\
\hline Clarias sp. & - & - & $\mathrm{N}=10 ; \mathrm{MNI}=6$ & $\mathrm{~N}=10 ; \mathrm{MNI}=4$ & 20 \\
\hline Siluriformes & - & - & $\mathrm{N}=1$ & $N=3$ & 4 \\
\hline \multicolumn{6}{|l|}{ Synbranchidae: } \\
\hline Monopterus albus & - & - & $\mathrm{N}=1$ & - & 1 \\
\hline \multicolumn{6}{|l|}{ Mastacembelidae: } \\
\hline Mastacembelus sp. & - & - & $N=1$ & - & 1 \\
\hline \multicolumn{6}{|l|}{ Nandidae: } \\
\hline Pristolepis fasciatus & - & - & $\mathrm{N}=3 ; \mathrm{MNI}=1$ & - & 3 \\
\hline \multicolumn{6}{|l|}{ Anabantidae: } \\
\hline Anabas testudineus & - & - & - & $\mathrm{N}=22 ; \mathrm{MNI}=5$ & 22 \\
\hline \multicolumn{6}{|l|}{ Belontidae: } \\
\hline Trichogaster pectoralis & - & - & - & $N=1$ & 1 \\
\hline \multicolumn{6}{|l|}{ Channidae: } \\
\hline Channa sp. & $\mathrm{N}=1$ & $N=1$ & $\mathrm{~N}=38 ; \mathrm{MNI}=8$ & $\mathrm{~N}=89 ; \mathrm{MNI}=16$ & 129 \\
\hline Sum $(\mathrm{N})$ & 1 & 1 & 153 & 214 & 369 \\
\hline Unidentified $(\mathrm{N})$ & - & - & 41 & 79 & 120 \\
\hline
\end{tabular}

Table 9. Measurements of Pig Bones

\begin{tabular}{lllllll}
\hline BONE & LOCATION & & & & \\
\hline Scapula & A/Burial 6 & KLC 26.5 & LG 32 & BG 27 & & \\
Radius & A/Burial 6 & GL 136 & Bp 30.7 & KD 22 & Bd 36 & $\begin{array}{c}\text { Distal epiphysis } \\
\text { in fusion }\end{array}$ \\
Metacarpus IV & Area S1/E1 & GL 74 & Bd 13.8 & & & \\
\hline
\end{tabular}

near water sources, feeding on grass, leaves, and fruits along the forest floor during the day. Similar to the two other species mentioned above, the muntjak (Muntiacus muntjak) was a common deer in Cambodia but is now endangered.

Another wild ruminant present in the faunal assemblage is the serow (Nemorhaedus sumatraensis). This large animal, characterized by some zoologists as a forest-living goatlike antelope (Soma 1988:505), could once be found all over Southeast Asia. In present-day Cambodia the species is restricted to the farthest northern and western regions. The serow is not an antelope but belongs to the subfamily Caprinae and is also related to the Rupicaprini (chamois). The animal 
Table io. Measurement of Dog Bones from S2EI, 3:3

\begin{tabular}{|c|c|c|c|c|}
\hline \multicolumn{5}{|l|}{ BONE } \\
\hline Femur & LC 213 & Bp 43.3 & KD 15.7 & Bd 39.3 \\
\hline Tibia & GL 196 & Bp 40.5 & KD 15.7 & Bd 25 \\
\hline Calcaneus & GL 53 & GB 21.5 & & \\
\hline Talus & GL 31.2 & BT 21 & GB 28 & \\
\hline Metacarpus & GL/Bd: McII 66/13 & McIII 74.5/10.6 & McIV 74/11 & McV 64.5/11 \\
\hline Metatarsus & GL/Bd: MtII 73.5/10 & MtIV 85.5/9.8 & & \\
\hline
\end{tabular}

has a short body and long legs measuring $85-94 \mathrm{~cm}$ in the withers. Unfortunately, none of the 11 bones recorded in the faunal assemblage was measurable. The serow is a solitary animal that inhabits arid mountains with open forest. As their preferred habitat does not exist near the site, the animals may have been hunted far away or brought to the site through trade or exchange.

In contrast to the serow, habitat suitable for boar did exist near the site. The only wild Sus species that occurs in Cambodia is the wild boar (Sus scrofa). This animal is capable of inhabiting a diverse range of habitats, avoiding only very arid areas. Just two bones from boar were recovered, which may indicate that the species was not widely hunted. It must be remembered, however, that only a small proportion of the site was excavated.

The three smaller wild carnivore species-jungle cat (Felis chaus), leopard cat (Prionailurus bengalensis), and binturong (Arctictis binturong)-live in different habitats. Whereas the jungle cat feeds in forests as well as in marsh- and grassland, the leopard cat is strictly a forest species, avoiding open country. The binturong is a type of civet of the family Viverridae. Civets live mainly nocturnally and arboreally in mature forests. All three species are represented by teeth whose features made identification unproblematic.

The only wild bird species present in the sample is the Sarus crane (Grus antigone). This bird requires open marsh- and grassland where it feeds on plants, small vertebrates, and nonvertebrates.

Besides deer, other prominent animal groups in the archaeological faunal assemblage from Phum Snay include tortoises and turtles. Most of the finds are fragments of carapace. Such animals are easy to acquire, and they can be collected alive. Painted batagur terrapin, a turtle species, and the softshell turtle may have been caught when fishing. The same is true for the crocodile, from which only small and medium-sized vertebrae remains have been found. As two crocodile species (Crocodylus siamensis and Crocodylus porosus) occur in the waters of northern Cambodia, identification to species level was not possible. A similar situation emerges for the bones of the monitor lizard: one skull fragment and two vertebrae. The two species to reckon with in the area are the two-banded monitor lizard (Varanus salvator) and the Bengal monitor (Varanus bengalensis).

While the sample of burial fauna revealed only two fish families (and numerous unidentified fish bones; see Table 6), the nonburial fish material is more diverse in composition. All fish species or families other than snakeheads, catfish, and cyprinids are represented by only one or a few specimens (Table 8 ).

The size variation within the most prominent fish groups (i.e., catfish or cypri- 
nids [particularly Bagridae, Siluridae, and Pangasidae] and snakeheads [Channa]) is remarkable. There are small specimens from the respective fish groups measuring less than $20 \mathrm{~cm}$ in length, medium-sized fish, and very large ones up to $80 \mathrm{~cm}$ in length. Members of the family Pangasidae, for example, are known to grow to considerable lengths. The largest specimen of the family Pangasidae found in a nonburial context probably measured almost $2 \mathrm{~m}$ in length (Table 8). Only one species of catfish (Pangasidae) that attains this size is recorded from Cambodian waters: Pangasius sanitwongsei (Rainboth 1996:157), known in Thailand as the Chao Phraya giant catfish. The large variation in body size is not only due to the fact that more than one species of the respective family is present in the sample but also indicates that different fishing grounds and fishing methods were used.

The small climbing perch (Anabas testudineus) lives in sluggish, standing, or even stagnant waters, often with dense vegetation. Most of the members of the family Channidae, especially when they are small, are found in comparable habitats. The same is true for the snake-skinned gourami (Trichogaster pectoralis) and the banded leaf fish (Pristolepis fasciatus), which are small fishes. The walking catfish (Clarias) prefers a similar habitat. These fishes can be caught in ponds and after the rainy season in flooded areas with the aid of baskets and nets or by hand.

As the Preah Net Prey River near Phum Snay is small, only smaller or medium-sized specimens could have been caught. These types of rivers may have housed medium-sized cyprinids and possibly the eel-like fish taxa, Mastacembelus and Monopterus albus.

The majority of the fish species/families listed in Tables 6 and 8 spend their life in large rivers. These are the Chitala sp., Cyclocheilichthys sp., Mystus sp., Wallago attu, and members of the family Pangasidae. On the assumption that the Preah Net Prey River has not changed its course in the last 1500 years and its river bed was not more expanded in ancient times, these fishes consequently must have been imported to Phum Snay, perhaps from the larger Kralangh River some 20$25 \mathrm{~km}$ distant from the site. The presence of these taxa at Phum Snay may suggest participation in short-distance trade networks.

\section{DISCUSSION}

The faunal assemblage from Phum Snay comprises two different components: animal bones as grave goods and bone fragments possibly originating from settlement activities. It is unlikely that the bones of the second group are contemporaneous with those in the burials.

The first group exhibits some highly characteristic features. The mammal and bird remains derive exclusively from domestic animals and include water buffalo, cattle, pigs, and possibly chickens. Fish also played a role in the grave cult. Judging from the species composition, the size of the fish bones, and the inclusion in ceramic vessels, they must have derived from prepared meals. Four burials from the excavation campaign of 2003 contained the left forelimbs of large bovids and pigs, complete from scapula to toe bones. These burial gifts were deposited either beside the body or at the head or feet. In two cases, mandibles of domestic pigs were also laid down in the graves.

Only adult buffalo bones were found in burial contexts. Cattle were offered ei- 
ther as adult or as almost fully grown young, and pig bones exclusively represent young animals. Both sexes of buffalo are represented as grave goods, but cattle bones found in burials came only from female animals.

When one considers the sex of the interred individual, it appears that men received the legs of buffalo and women those of cattle. This observation is only valid for the area excavated during 2003 (Burials '03/5 to '03/7, and '03/13). Based on the sample size, however, it would be imprudent to say that this was the case for any significant portion of the cemetery at Phum Snay. Higham's (1989:90ff.) research in northeastern Thailand indicates that prehistoric burial rites were varied from site to site. Most of these Thai sites date much earlier than Phum Snay and the animal bones have been studied in extenso only from a few of them (Higham 1975; Higham and Kijngam 1979; Higham and Kijngam 1982; see also Higham and Thosarat 2002:159ff.).

The burials in the area excavated in 2001 (Burials '01/3, '01/6, and '01/9) present a somewhat different situation. Here also, only the remains of domesticated animals were found, but instead of forelimbs, a pig mandible (Burial '01/3, sex unknown), a left hind cattle's foot (Burial '01/6, probable male), and a horn-core of a buffalo (Burial '01/9, male) were encountered.

The animal bones found in nonburial contexts reveal a broad-spectrum foraging economy that exploited a wide range of ecosystems: forests, grassand marshlands, rivers, and inundated fields, resulting in the catch of deer, boar, smaller carnivores, cranes, tortoises, turtles, monitor lizards, crocodiles, and fish. The majority of the hunt was deer, represented in the sample by three different species (Table 7). Deer, wild cats, and binturong are adapted to jungles and forests. The site's current environment is a man-made landscape with cultivated fields. This environment will not support forest-dwelling species, suggesting that there were more forested areas at the site in prehistoric times.

There are many possible variations in Southeast Asian village economies based on rice, cattle, pig and water buffalo breeding, fishing, plant collecting, and hunting of wild ungulates (Higham and Thosarat 1998; 2002). Burial rituals in prehistoric sites in northeastern Thailand are broadly similar to those at Phum Snay. Many of the offerings are similar and placed in a similar way.

The analysis of the animal bones excavated from the burials at Phum Snay revealed some unique aspects of the ancient rituals practiced during the first centuries A.D. From our observations it can be seen that, preferentially, left forelimbs of domestic ungulates have been deposited as grave goods. In addition, the presence of the zebu cattle in this part of Southeast Asia could be evidenced for the first time. However, considering the overall small sample size on which our conclusions are based, investigations of contemporaneous cemeteries in the study area are necessary for a better understanding of the role animals played in the cult of the deceased.

\section{ACKNOWLEDGMENTS}

The Ford Motor Company and the Center for Khmer Studies supported the research presented in this study. The authors are indebted to Prof. Dr. Michael Roaf, the Institute for Near Eastern Studies of the University of Munich, the Royal Uni- 
versity of Fine Arts, the Royal Government of Cambodia, the Ministry of Culture and Fine Arts, Dr. Nancy Beavan Athfield, Dr. Kate Domett, and the people of Phum Snay.

\section{REFERENCES CITED}

Chetwin, J.

n.d. A case in points: Hunting, conflict and the terminal Iron Age at prehistoric Noen ULoke, Nakhon Ratchasima Province, Thailand. Unpublished ms. on file, Department of Anthropology, University of Otago.

Corbet, G. B., AND J. E. Hill

1992 The Mammals of the Indomalayan Region: A Systematic Review. Oxford, UK: Natural History Museum Publications.

Dометт, K.

n.d. The skeletal remains from Phum Snay, Cambodia. Unpublished ms. on file, Department of Anthropology, University of Otago.

Driesch, A.v.D.

1976/ A Guide to the Measurement of Animal Bones from Archaeological Sites. Cambridge, MA: Pea1999 body Museum of Archaeology and Ethnology, Harvard University.

Harcourt, R. A.

1974 The dog in prehistoric and early historic Britain. Journal of Archaeological Science 1:151175.

HighaM, C.F.W.

1975 Non Nok Tha: The Faunal Remains. Dunedin, New Zealand: University of Otago.

1989 The Archaeology of Mainland Southeast Asia: From 10,000 B.C. to the Fall of Angkor. Cambridge, UK: Cambridge University Press.

1998 Noen U-Loke and the implications for the origins of early states. Unpublished paper presented at the 16th Congress of the Indo-Pacific Prehistory Association. Melaka, Malaysia.

Higham, C.F.W., and A. KiJngam

1979 Ban Chiang and Northeast Thailand: The palaeoenvironment and economy. Journal of Archaeological Science 6:211-234.

1982 Prehistoric man and his environment: Evidence from the Ban Chiang faunal remains. Expedition $24: 17-24$.

Higham, C.F.W., and R. Thosarat

1998 Prehistoric Thailand: From Early Settlement to Sukhothai. Bangkok: River Books.

2002 Early Cultures of Mainland Southeast Asia. Bangkok: River Books.

KURT, F.

1988a Sambar- oder pferdehirsche (Untergattung rusa), in Grzimeks Enzyklopädie der Säugetiere 5: 164-171. München: Kindler.

1988b Muntiakhirsche, in Grzimeks Enzyklopädie der Säugetiere 5: 137-139. München: Kindler.

O'ReILly, D.J.W.

1998 The discovery of clay-lined floors at an Iron Age site in Thailand: Preliminary observations from Non Muang Kao, Nakon Ratchasima Province. Journal of the Siam Society 85(1):1-14.

RAINBOTH, W. J.

1996 Fishes of the Cambodian Mekong. Rome: FAO.

SOMA, $\mathrm{H}$.

1988 Seraue (Gattung Capricornis), in Grzimeks Enzyklopädie der Säugetiere 5: 505-506. München: Kindler.

STARK, M. T.

2004 Pre-Angkorian and Angkorian Cambodia, in Southeast Asia: From Prehistory to History: 89-119, ed. I. Glover and P. Bellwood. New York: Routledge Curzon.

WICHAKANA, $M$.

1991 Prehistoric sacrifices at Noen-U-Loke (in Thai). Muang Boran 16(4) : 69-79. 


\section{ABSTRACT}

This paper analyzes faunal remains excavated from the late prehistoric cemetery of Phum Snay in northwestern Cambodia. The material comprises two different components: (1) animal bones as grave goods and (2) bone fragments originating from settlement activities. The mammal and bird remains from the graves derive exclusively from domestic animals and include water buffalo, cattle, pigs, and possibly a chicken. In most cases, one or two limbs from the left side of the body of one or two species were deposited in a grave. Fish were also incorporated in the grave cult. The animal bones found in nonburial contexts reveal a broad-spectrum foraging economy that exploited a wide range of ecosystems: forests, grass- and marshlands, rivers, and inundated fields, resulting in the capture of deer, boar, smaller carnivores, cranes, tortoises, turtles, monitor lizards, crocodiles, and fish. Keywords: animal bones, burial goods, economic activities, late prehistoric time, Cambodia. 